\title{
IMPACT OF FLOODING ON LAND USE/ LAND COVER TRANSFORMATION IN WULAR LAKE AND ITS ENVIRONS, KASHMIR VALLEY, INDIA USING GEOINFORMATICS
}

\author{
Tauseef Ahmad ${ }^{1 *}$, A.C. Pandey ${ }^{2}$, Amit Kumar ${ }^{3}$
}

\begin{abstract}
${ }^{1}$ Centre for Land Resource Management, Central University of Jharkhand, Ranchi, India - tauseef@cuj.ac.in ${ }^{2}$ Centre for Land Resource Management, Central University of Jharkhand, Ranchi, India - arvindchandrap@yahoo.com ${ }^{3}$ Centre for Land Resource Management, Central University of Jharkhand, Ranchi, India-amit.kumar@cuj.ac.in
\end{abstract}

KEY WORDS: Lake Environment, Flood inundation, Land Use/ Land Cover, Geoinformatics. Supervised classification

\begin{abstract}
:
Wular lake, located at an elevation of $1520 \mathrm{~m}$ above sea level in Kashmir valley, India. In the present study, the immediate and long term impact of flood (2014) over the Wular lake environs was analyzed by using satellite images and employing supervised classification technique in GIS environment. The LULC classification was performed on the images of 25 ${ }^{\text {th }}$ August 2014 (pre flood) and $13^{\text {th }}$ September 2015 (post flood) and was compared, which indicated marked decrease in terrestrial vegetation (23.7\%), agriculture (43.7\%) and water bodies (39.9\%). Overlaying analysis was performed with pre and post flood classified images with reference to the satellite image of $10^{\text {th }}$ September 2014(during flood) which indicated total area inundated during flood was $88.77 \mathrm{~km}^{2}$. With the preflood situation, the aquatic vegetation of $34.06 \mathrm{~km}^{2}, 13.89 \mathrm{~km}^{2}$ of agriculture land and terrestrial vegetation of $3.13 \mathrm{~km}^{2}$ was inundated. In the post flood situation, it was also came into focus that more than the half of the area under water bodies was converted into sand deposits $\left(22.76 \mathrm{~km}^{2}\right)$ due to anomalous increase in siltation. The overlay analysis on post flood classified image indicated that aquatic vegetation followed by agriculture and sand deposits lie within the flood inundated area. Further spatial analysis was performed within the flood inundated area $\left(88.77 \mathrm{~km}^{2}\right)$ with pre and post classified image to understand the situation before and after the flood and to calculate the changes. These land use-land cover transformations signifies the ill effect of flooding on the biodiversity of Wular Lake.
\end{abstract}

\section{INTRODUCTION}

Lakes are formed in the rock basins having different shapes and sizes. It classified into glacial, Alpine and valley depending upon their origin, height and nature of biota and provide to opportunity to study the structure and functional process of an aquatic ecosystem system (Kaul 1977;; Trisal 1985; Zutshi et al 1972). Lakes stores and regulate the flow of water but when they become smaller due to eutrophication, flooding occurs as the regulation of the flow become less and causes flood. The occurrence of floods is the most frequent among all natural disasters. Flood hazard mapping vulnerability assessment plays an important component for land use planning in areas affected by flood. The high risk areas correspond to high hazard and vulnerability which are extremely prone to flood and also vulnerable to these hazards from point of socio-economic (Pandey et al., 2010). Land use transformation is very useful using satellite data in GIS environment in order to monitor land consumption rate (Kumar et al., 2011).

Very significant studies on Kashmir valley lakes (Hamilton and Schaldow, 1997; Subramanium, 2000; Bhatt, 2004; Agarwal et al., 2012) indicated the aspects of high altitude lakes in India. Structurally, the valley of Kashmir is an intermontane basin, (Agarwal and Agarwal, 2005; Burbank and Johnson, 1982;

*Corresponding author (email: tauseef@cuj.ac.in)
Dubey and Dar, 2015) which is entirely filled with PlioPleistocene deposits and lies between the range of Pir Panjal and the Great Himalayan. Records of past floods in the Srinagar region of Kashmir valley are meagre and flood on $10^{\text {th }}$ September 2014 remarked as incidental flooding. Flood during 2014 destroyed the major parts and planning is needed for flood management in future to safeguard the inhabitants under erratic and extreme rainfall (Ahmad et al., 2017). The flood has a significant effect on the population (Mishra, 2015).

Wular Lake is the Asia's largest lake in which several rivers (like Madhumati, Sukh Nag, Dudganga, Erin Nala and Kausar Nag) drains into it. The drains carry large amounts of sediments, which are deposited in the lower courses and making beds shallower and limiting full discharge and causing flood. Due to eutrophication process, Wular lake is losing its water holding capacity in order to deal with the problem of flood (Mushtaq et al., 2015). The climatic condition is also an important factor responsible for the decrease in water level and water spread as the discharge by the major tributaries decreased in the Wular lake (Mushtaq et al., 2013).

The flood hazards and risks assessment and to prepare effective flood mitigation measures and utilizing flood benefits meanwhile have become more vital task in water resource planning and flood management. Therefore, in the present study, the land use/ land cover was mapped and correlated with the 
flood inundation situated to analyze the immediate and long term flood impact over the varied LULC.

\section{STUDY AREA}

Wular lake is located in Jammu and Kashmir and about $37 \mathrm{~km}$ (north-west) away from the capital city, Srinagar. The study area lies between $34^{\circ} 15^{\prime}-34^{\circ} 26^{\prime} \mathrm{N}$ latitudes and $74^{\circ} 28^{\prime}-74^{\circ} 40^{\prime} \mathrm{E}$ longitudes. The total area under study is $293 \mathrm{~km}^{2}$ with the average relief of $1520 \mathrm{~m}$ above mean sea level (Figure 1). The region receives precipitation both in the form of rain and snow. The Kashmir valley receives annual average precipitation of 650 $\mathrm{mm}$, which is often higher in the outer hilly regions as compared to the central valley. The average temperature ranges from $19.8^{\circ} \mathrm{C}$ in summer (June-August; Husain 1998) to $7.5^{\circ} \mathrm{C}$ in winter (November to March) and sometimes reaches to the minimum of $0^{\circ} \mathrm{C}$. The Wular lake is surrounded by the deciduous vegetation with the trees like Chinar, Poplar, Deodar, Fir, Pine, Kail, Partal, Mulbery, Walnut and other fruits. The streams like Madhumati, Sukh Nag, Dudganga, Erin Nala and Kausar Nag flow into the lake, where Jhelum River is the main feeding river and seeks the passage into Wular lake. Anchar lake, Manasbal and Dal lake are some of the larger wetland in the valley which are facing a major threat due to urbanization. Dal lake is situated in the Srinagar city which is a man-made lake. Therefore in the present study analysis was performed for the naturally formed Wular lake.

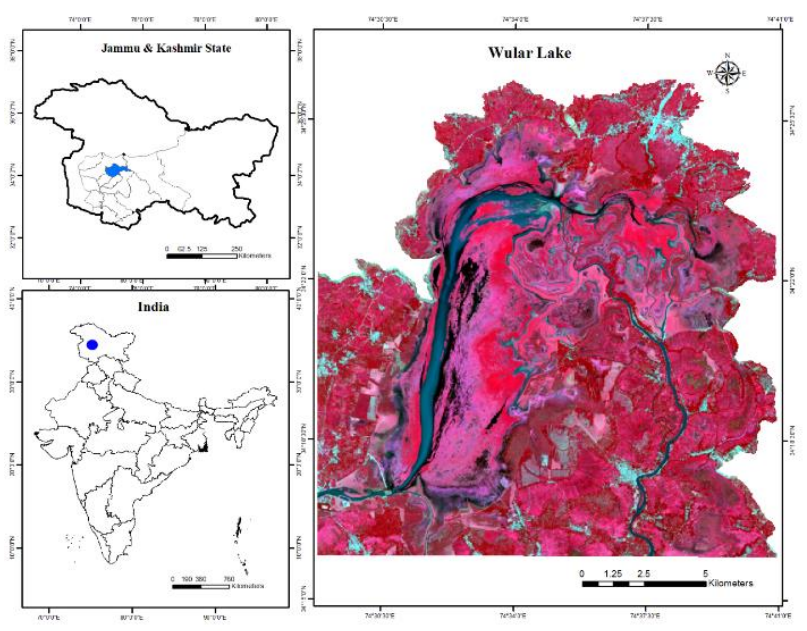

Figure 1. Location map of the study area along with satellite image (25 August 2014) of Wular lake and its environs

\section{DATA AND METHODOLOGY}

In the study, analysis on various satellite data was used to understand the effect of flood $\left(10^{\text {th }}\right.$ September 2014) on the LULC of Wular lake (Table 1). The satellite images of LANDSAT (25 ${ }^{\text {th }}$ Aug. 2014, 10 $0^{\text {th }}$ September 2014 and $13^{\text {th }}$ September 2015) were acquired from USGS website (http://earthexplorer.usgs.gov) and used for LULC map preparation. The study area was clipped according to an elevation of $1625 \mathrm{~m}$ (a.m.s.l) in the north and eastern side using ASTER DEM. The supervised classification was performed to delineate LULC classes viz., terrestrial vegetation, aquatic vegetation, agriculture, settlement, water bodies, others and sand deposits. The vegetation grown in water bodies are considered as aquatic vegetation, all the cultivated areas including fallow land and plantation are considered as agriculture land, evergreen/semi-evergreen forest, deciduous and scrub forest are considered as terrestrial vegetation whereas the settlement includes manmade area, which covers buildings, transport and all water covered area are considered as water bodies. The satellite image of $10^{\text {th }}$ September 2014 was used to map flood water and its impact over varied LULC. The quality of a supervised classification technique depends on the validity of the training sets (Palaniswami et al. 2006). Therefore, in the present study, 91 training sets were selected in order to perform correct classification. The Kappa coefficient was performed for the assessing the accuracy of land-use classifications (Peng et al. 2008). The methodology adopted in the present study is given in flowchart (Figure 2).

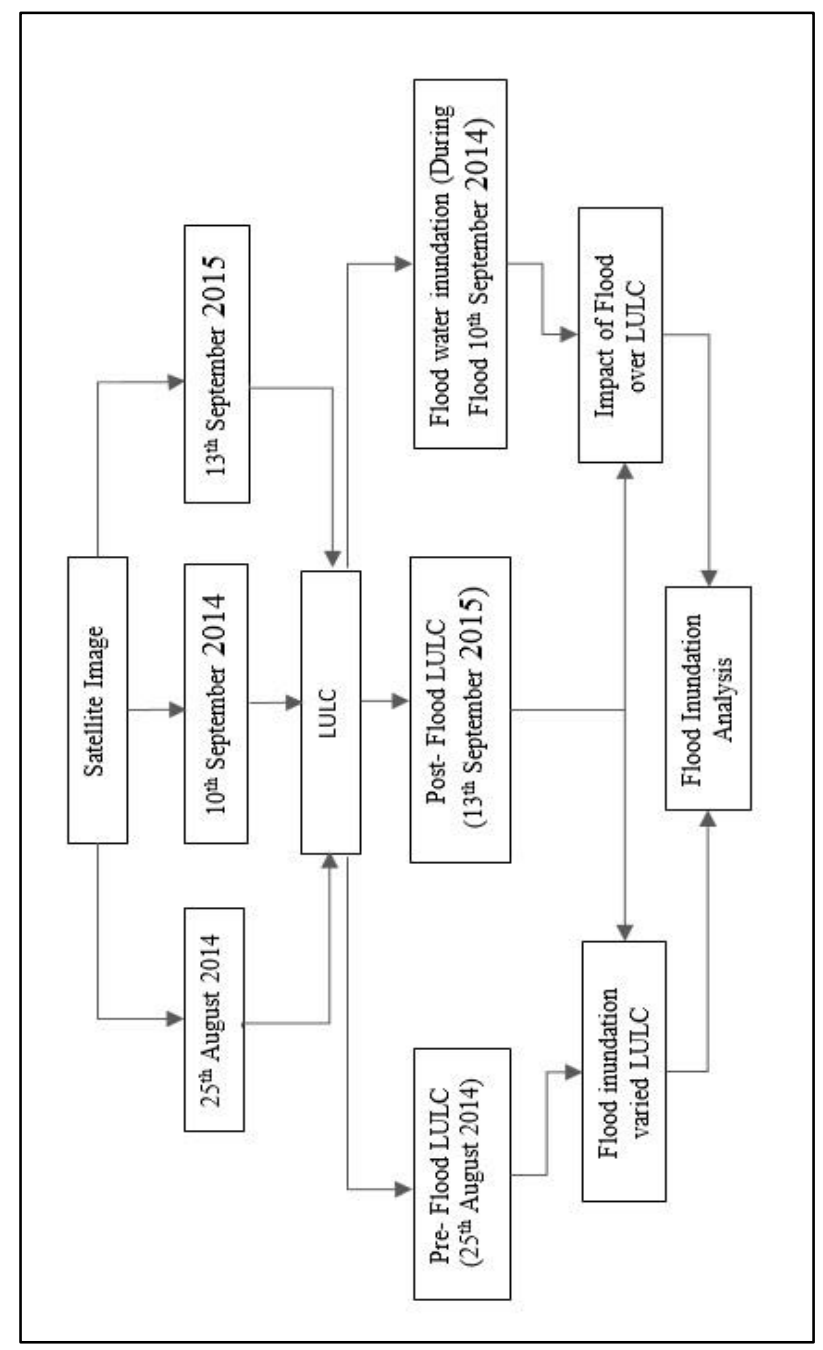

Figure 2. Flowchart of the methodology 
Table 1: Details of satellite data used in the study

\begin{tabular}{|c|c|c|c|}
\hline $\begin{array}{ll}\text { Name } & \text { of } \\
\text { Satellite }\end{array}$ & Sensor & $\begin{array}{c}\text { Date of } \\
\text { acquisition }\end{array}$ & $\begin{array}{l}\text { Resolution } \\
\text { (m) }\end{array}$ \\
\hline LANDSAT $7 * \AA$ & ETM+ & $25^{\text {th }}$ Aug.2014 & 30 \\
\hline LANDSAT $8 * \AA$ & OLI & $10^{\text {th }}$ Sept.2014 & 30 \\
\hline LANDSAT $8 * £$ & OLI & $13^{\text {th }}$ Sept.2015 & 30 \\
\hline
\end{tabular}

The overall accuracy was calculated for the LULC map based on selective field checks during the month of April 2016 and using Google Earth images, the overall classification for year $25^{\text {th }}$ August 2014, $10^{\text {th }}$ September 2014 and $13^{\text {th }}$ September 2015 was calculated to be $93 \%, 94 \%$, and $95 \%$ respectively with the Kappa Coefficient of $0.801,0.670$ and 0.8907 respectively (Table 2). The revised classification was used for area calculation and further analysis by correcting the wrong identified pixels. The area statistics of these categories was calculated from the classified images and analyzed in geospatial environment to deduce the effect of flood inundation.

Table 2: Accuracy assessment of LULC maps of 25 Aug. 2014, 10 Sept. 2014 and 13 Sept. 2015

\begin{tabular}{ccc}
\hline Sensors/Year & $\begin{array}{c}\text { Overall } \\
\text { accuracy }\end{array}$ & $\begin{array}{c}\text { Kappa } \\
\text { coefficient }\end{array}$ \\
\hline $25^{\text {th }}$ Aug.2014 & $93.00 \%$ & 0.8012 \\
\hline $10^{\text {th }}$ Sept. 2014 (Flood) & $94.00 \%$ & 0.6700 \\
\hline $13^{\text {th }}$ Sept. 2015 & $95.00 \%$ & 0.8907 \\
\hline
\end{tabular}

\section{RESULTS AND DISCUSSIONS}

The land use/ land cover classification of Wular lake and its environs during pre-flood (August 2014) and post flood (September 2014) situation was analyzed in order to deduce the immediate and long term impacts of flood inundation condition over varied land uses/ cover.

\subsection{Land Use/ Land Cover Mapping}

The pre-flood LULC mapping using LANDSAT $7 \mathrm{ETM}^{+}$ satellite image (dated $25^{\text {th }}$ August 2014) exhibits that agriculture land was the major LULC class covering $113.34 \mathrm{~km}^{2}$ (38.73\% of total area) followed by aquatic vegetation $\left(74.83 \mathrm{~km}^{2} ; 25.57 \%\right)$, water bodies $\left(44.44 \mathrm{~km}^{2} ; 15.19 \%\right)$, terrestrial vegetation $(40.92$ $\left.\mathrm{km}^{2} ; 13.98\right)$, settlement $\left(12.73 \mathrm{~km}^{2} ; 4.35 \%\right)$ and others $(6.38$ $\mathrm{km}^{2} ; 2.18 \%$ ) in 2014 (Table 3 and Figure 3 (a.1 and a.2)).

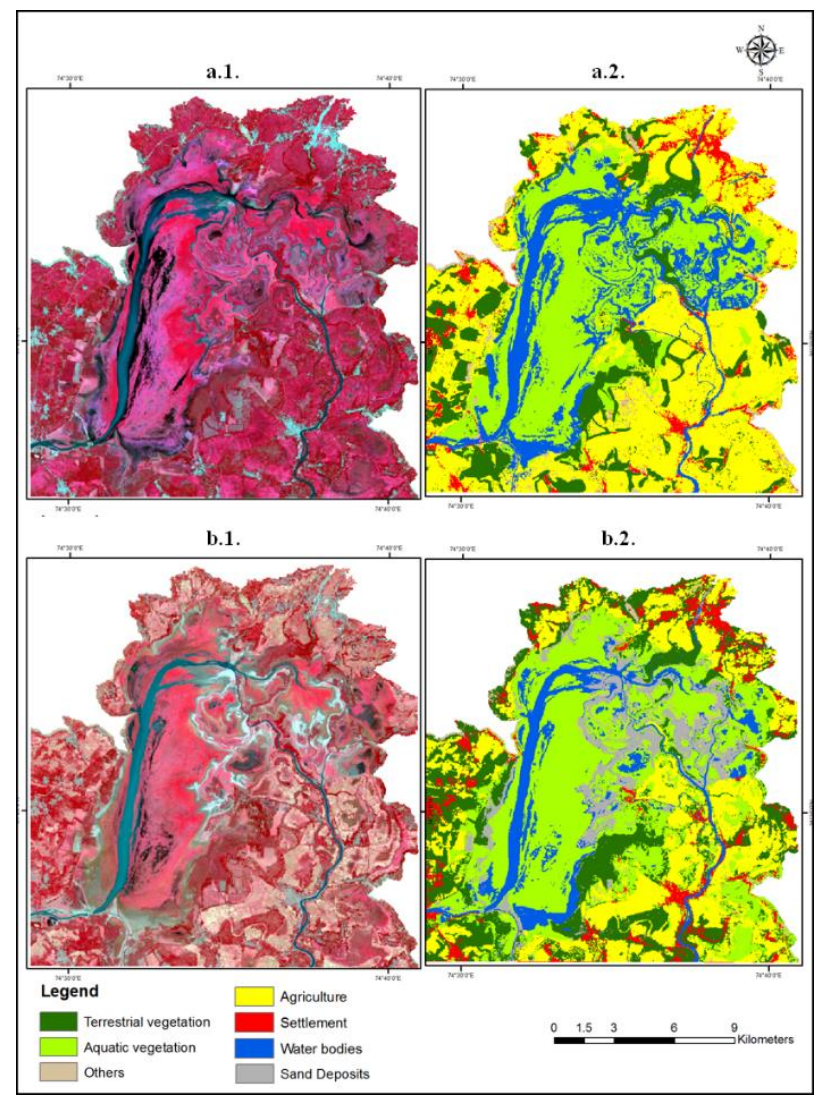

Figure 3. Satellite images of pre flood (a.1.) and post flood (b.1.) and respective LULC classified image (a.2.) and (b.2.)

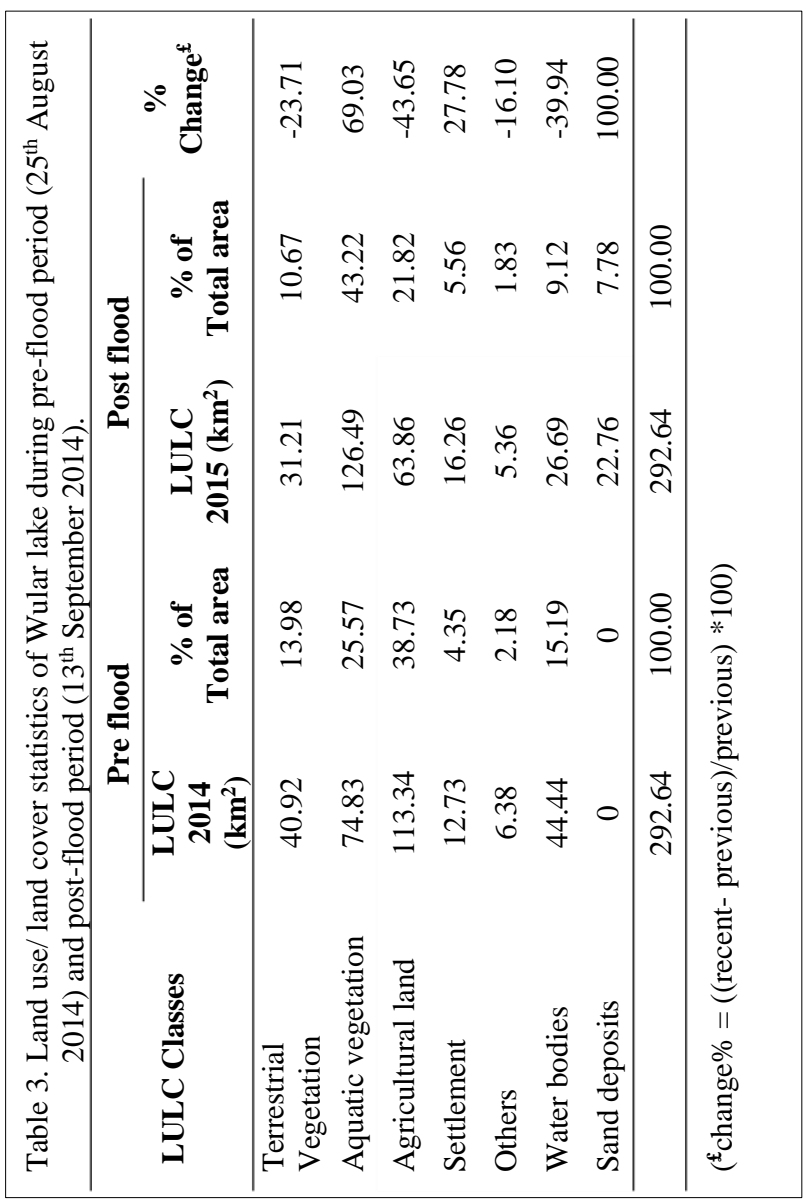


The post flood LULC mapping using LANDSAT 8 OLI satellite image (dated of $13^{\text {th }}$ September 2015) exhibits that the aquatic vegetation was the major LULC covering an area of $126.49 \mathrm{~km}^{2}$ (43.22\%), followed by terrestrial vegetation covers area of 31.21 $\mathrm{km}^{2}(10.67 \%)$ whereas rest of the area was covered by agriculture of $63.86 \mathrm{~km}^{2}(21.82 \%)$, settlement of $16.26 \mathrm{~km}^{2}$ $(5.56 \%)$, water bodies of $26.69 \mathrm{~km}^{2}(9.12 \%)$, others of $5.36 \mathrm{~km}^{2}$ $(1.83 \%)$ and sand deposits of $22.76 \mathrm{~km}^{2}(7.78 \%) \mathrm{km}^{2}$ (Table 3 and Figure 3(b.1 and b.2)).

The LULC map during pre and post flood situation was compared, which shows that the maximum change occurred in the aquatic vegetation (69.03\%) and settlement (27.78\%). Whereas the negative change was observed in agriculture land ($43.65 \%)$ followed by water bodies $(-39.94)$, terrestrial vegetation $(-23.71 \%)$ and others $(-16.10 \%)$ during 2014-15. This decrease in majority of LULC may be attributed to the formation of sand deposits $\left(22.76 \mathrm{~km}^{2} ; 100 \%\right)$ due to high siltation during 2014 flood.

\subsection{Impact of flood inundation (September 2014) on land use/ land cover}

Satellite image of $10^{\text {th }}$ September 2014 was used to map flood inundation in the study area (Figure 4). The total of $88.77 \mathrm{~km}^{2}$ $(30.3 \%)$ was observed inundated covering primarily in the central part of the study area. Whereas the non-inundated area located in the north and southeastern part having higher elevation covering $203.87 \mathrm{~km}^{2}(69.6 \%)$ (Table 4).

\begin{tabular}{lcc}
\hline \multicolumn{3}{c}{ Table 4. Flood water area coverage during flood period as on } \\
$10^{\text {th }}$ September 2014
\end{tabular}

The flood inundation map (10 ${ }^{\text {th }}$ September 2014) was overlaid on the pre flood LULC map ( $25^{\text {th }}$ August 2014) to understand the flood inundation on the different LULC class. The result depicted that $3.13 \mathrm{~km}^{2}(3.5 \%)$ of terrestrial vegetation was inundated during $25^{\text {th }}$ August 2014 (Table 5). The maximum inundation was calculated in the Aquatic vegetation with $34 \%$ of total area with least inundation in settlement with $0.4 \%$ of total area. The agriculture class was mostly effected by the flood as $15.6 \%$ of total area inundated.
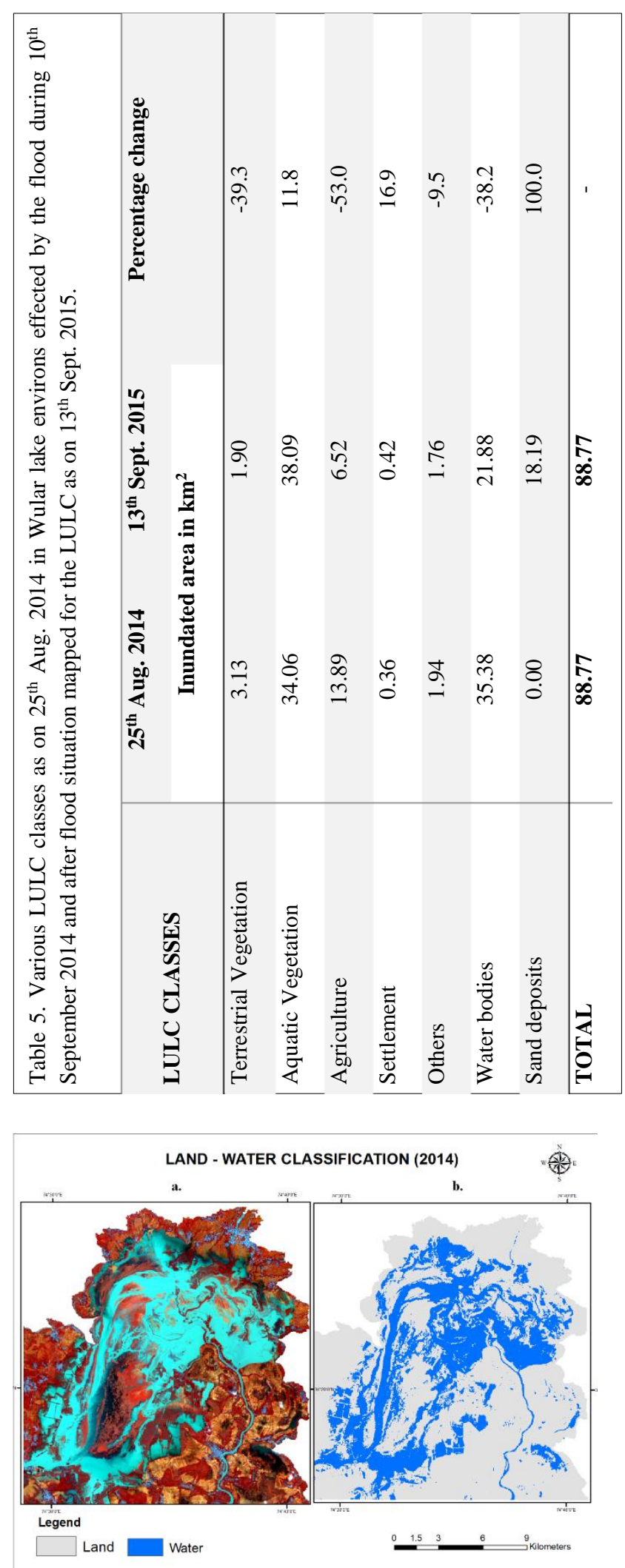

Figure 4. (a) LANDSAT OLI satellite image (as viewed on $10^{\text {th }}$ September 2014: during flood situation) and (b) flood water inundation map

To deduce the significant flood impact long after flood situation (Aug. 2014), the flood inundation map was overlaid on the post flood LULC map (Sept. 2015). It depicts that aquatic vegetation 
was most affected class as $38.09 \mathrm{~km}^{2}$ was inundated $(42.9 \%$ of total inundation) followed by water bodies $21.88 \mathrm{~km}^{2}(24.6)$, agriculture $6.52 \mathrm{~km}^{2}(7.3 \%)$, Terrestrial vegetation $1.9 \mathrm{~km}^{2}$ $(2.1 \%)$ along with settlement inundated of $0.42 \mathrm{~km}^{2}(0.5 \%$ of total inundation) during $13^{\text {th }}$ September 2015 . This exhibits that the settlement area are in upper part of the Wular lake and the bank of lake are higher in comparison to lake making settlement are much safer. $18.19 \mathrm{~km}^{2}(20.5 \%)$ was covered by sand deposit during the post flood situation due to high siltation.

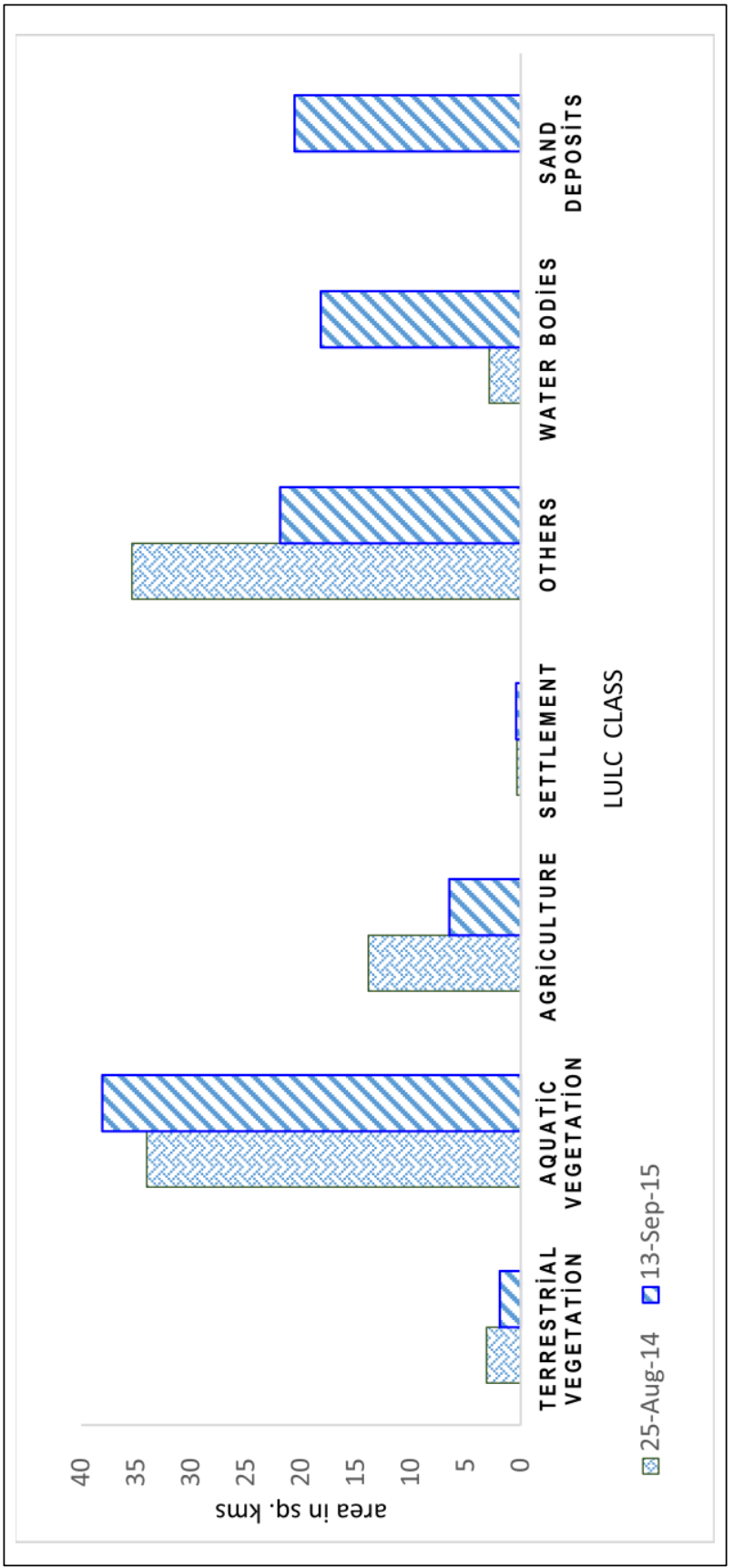

The variation in the class of LULC in terms of inundation was also analyzed (Figure 5). The three class agriculture, aquatic vegetation and others are largely inundated by the flood in both the pre and post situation. This can be understood that the agriculture area are the low lying area for which they can receive water regularly for the cultivation of crops whereas the wasteland and scrub land are also found in the same scenario. Aquatic vegetation are lying in the water so the inundation in this class was obvious and transforming the water quality parameters influencing the lake ecosystem. The high siltation leads to formation of sand deposit covering $20.5 \%$ of total area, which were primarily agriculture land and aquatic during pre-flood situation.

\section{CONCLUSION}

In the present study, the impact of flood inundation in varied LULC classes was studied to understand the immediate and long term impact of flood (2014). The study shows that total 88.77 $\mathrm{km}^{2}$ area was inundated due to flood. The comparative assessment between pre and post flood situation indicated changes with increase in the aquatic vegetation $(69.0 \%)$ and decrease in terrestrial vegetation (23.7\%), agriculture (43.7\%), water bodies (39.9\%) and others (16.1\%). Due to lesser impact of flood on settlement, the said class increased by $27.8 \%$ during 2014-2015 primarily in the higher locations. The $22.76 \mathrm{~km}^{2}$ area of sand deposits was observed during post flood period, which leads to decrease in area of aquatic vegetation, agriculture and water bodies. The pre-flood LULC mapping exhibits that agriculture land was the major LULC $\left(113.34 \mathrm{~km}^{2}\right)$, followed by aquatic vegetation $\left(74.83 \mathrm{~km}^{2}\right)$, water bodies $\left(44.44 \mathrm{~km}^{2}\right)$, terrestrial vegetation $\left(40.92 \mathrm{~km}^{2}\right)$. The flood inundation was observed in $88.77 \mathrm{~km}^{2}$ area, which primarily inundated aquatic vegetation $\left(34.06 \mathrm{~km}^{2}\right)$, water bodies $\left(35.38 \mathrm{~km}^{2}\right)$ and agriculture $\left(13.89 \mathrm{~km}^{2}\right)$. As flood inundation in water bodies and aquatic vegetation was observed as a natural process having insignificant impact over human settlements rather affected the lake ecosystem. The $0.36 \mathrm{~km}^{2}(2.82 \%)$ of area under settlement located immediate to Wular lake was inundated, indicating that the most of the population resides on the safer part in the region. The post flood situation was analyzed with respect to the land use/ land cover change as a part of flood inundation impacts. The study exhibits that the major part of agricultural land, terrestrial vegetation and others LULC classes were primarily affected and decreased $\left(63.86 \mathrm{~km}^{2}, 31.21 \mathrm{~km}^{2}, 5.36 \mathrm{~km}^{2}\right.$ respectively). On the contrary, majority of said LULC classes were covered by sand deposits $\left(22.76 \mathrm{~km}^{2}\right)$ influencing the ecosystem process of lake environment. It also came into focus that $39.94 \%$ under water bodies were converted into sand deposits $\left(17.75 \mathrm{~km}^{2}\right)$. This sand deposits detriment the aquatic vegetation and agricultural area even unbalancing the aquatic life of lake. These changes and post flood situation exhibits the impact of catastrophe flood on the biodiversity of Wular lake. This work is multi-temporal dataset approach, which revealed changes due to flooding is accurate therefore can be adopted by the government to formulate measures to combat ill effect of flooding in highly fragile natural lake ecosystem. Future studies can be taken up to compare changes in natural (Wular lake) and manmade lake (Dal lake) ecosystem during flooding. 


\section{ACKNOWLEDGEMENTS}

The authors would like to acknowledge USGS for online availability of LANDSAT satellite data. First author acknowledges the financial assistance under the UGC Maulana Azad National Fellowship (Government of India).

\section{REFERENCES}

Agarwal, K.K., and Agarwal, G.K., 2005. Sandbox analogue model an example from the Karewa basin, Kashmir Himalayas, India. Internat. Jour. Earth Sci., v.94, pp.47-52.

Agarwal, K.K., Prakash, C., Ali, S.N. and Jahan, N., 2012. Morphometric analysis of Ladhiya and Lohawati river basins, Kumaun Lesser Himalaya, India. Zeitschrift fur Geomorphologie, v.56, pp.201-224.

Ahmad, T., Pandey, A.C., Kumar, A., 2017. Evaluation of flood impacts vis-à-vis urban sprawl and changing climate in Srinagar city and its environs. SGVU J Clim Change Water Vol. 1 (2), 3846 Vol. 1 (2) pp. 38-46 ISSN: 2347-7741.

Bhatt, S., 2004. Proceedings of the National Conference on Kashmir, Ecology \& Environment: New concerns \& strategies; In: Major environmental issues in Kashmir (ed.) Bhatt S, APH Publishing Corporation, New Delhi, pp.91-98.

Burbank, D.W., and Johnson, G.D., 1982. Intermontane development in past $4 \mathrm{Ma}$. in the Northwest Himalaya. Nature London, v.289, pp.232-236.

Dubey, R. K., and Dar, J. A., 2015. Geotechnical susceptibility constraints on seismicity of Karewa Group and its implications in quaternary earthquakes around Kashmir Valley, India. Geotech. Geol. Eng. DOI 10.1007/s 10706- 015-9844-1.

Hamilton, D.P., and Schaldow, S.G., 1997. Prediction of water quality in lakes and reservoirs. Part I - Model description; Ecol. Model, v.96, pp.91-110.

Husain, M., 1998. Geography of Jammu and Kashmir, 2nd ed. Rajesh Publication, New Delhi, India.

Kaul, V., 1977. Limnological Survey of Kashmir Lakes with Reference to Trophic Status and Conservation. Internat. Jour. Ecol. Environ. Sci., v.3, pp.29-44.

Kumar, A., Pandey, A.C., Hoda, N., Jeyaseelan, A.T., 2011. Evaluating the long-term urban expansion of Ranchi Urban Agglomeration, India using geospatial technology. J. Indian Soc. Remote Sens. 39 (2), 213-224.

Mishra, A., 2015. A study on the occurrence of flood events over Jammu and Kashmir during September 2014 using satellite remote sensing. Nat Hazards 78:1463-1467. DOI 10.1007/s11069-015-1768-9.
Mushtaq, F., and Pandey, A.C., 2013. Assessment of land use/land cover dynamics vis-à-vis hydrometeorological variability in Wular Lake environs Kashmir Valley, India using multitemporal satellite data. Arab J. Geosci. 7, 4707 (2014). doi:10.1007/s12517-013-1092-1.

Mushtaq, F., Lala, M.G.N., Pandey, A.C., 2015. Assessment of pollution level in a Himalayan Lake, Kashmir, using geomatics approach, International Journal of Environmental Analytical Chemistry, 95:11, 1001-1013.

Palaniswami, C., Upadhyay, A.K., Maheswarappa, H.P., 2006. Spectral mixture analysis for subpixel classification of coconut, Curr. Sci., 91(12), 1706 -1711.

Pandey, A.C., Singh, S.K., Nathawat, M.S., 2010. Water logging and flood hazards vulnerability and risk assessment in Indo Gangetic plain. Nat Hazards 55:273-289. doi:10.1007/s11069010-9525-6.

Peng, J., WU, J., Yin, H., Li, Z., Chang, Q., and Mu, T., 2008. Rural land use change during 1986-2002 in Lijiang, China, based on remote sensing and GIS data. Sensors, 8, pp. 82018223 .

Subramanium, V., 2000. Water Quantity and Quality Perspective in SouthAsia. England: Kingston International Publishers, pp.113.

Trisal, C.L., 1985. Trophic status of Kashmir Valley lakes. Geobios Spl. Vol- I.17179. In: Mishra S.D., Sen, D.N., Ahmed, I. (Eds) Proc. National Symposium on Evaluation of Environment, Jodhpur, India.

Zutshi, D.P., Kaul, V., and Vass, K.K., 1972. Limnological Studies of High Altitude Kashmir lakes. Verhandlungen des Internationalen Verein Limnologie, v.118, pp.599-604. 